\title{
Reform Curriculum to Highlight the Character of Higher Vocational College P.E.
}

\author{
Wenjun ZENG \\ Liuzhou Railway Vocational Technical College, Liuzhou, 545007, China \\ Email: zengwj1969@sina.com
}

Keywords: Vocational College P.E., Character, Teaching Contents, Reform

\begin{abstract}
Teaching content of public physical education in higher vocational college should be reset, to assume the main task that cultivate students' occupation physical, make the character and special requirements of higher vocational school physical education reflected and brought into play.
\end{abstract}

\section{Introduction}

What higher vocational educational cultivate is applied-type skill talents in production, construction, management and service. "Higher vocational education is required to cultivate students to get an ability to adapt to a job directly; students can work after graduation immediately. And the occupation post requests higher and more directly in the workers' physical fitness" ${ }^{\text {"[1] }}$.Higher vocational school public physical education should take responsibilities of matching the major that students study, and cultivating students' professional fitness, so that they can adapt their career. However, this teaching target is indeterminate in traditional higher vocational school P.E., it never thought about students' major and the requirements of profession in the past, therefore, course content is still falling behind the requirements of developing vocational education, the special requirements and character of $\mathrm{PE}$ are never expressed, moreover, it is hard to achieve a good results for students' work in future.

In order to meet the need of society and conform the developments of higher vocational education, P.E. should be oriented toward students' professional characteristics and their future post characteristics, reset the teaching contents, teach students can not only exercise in playgrounds, but also regulate their bodies in places of practice. Besides, they can suit their measures to local conditions using existing facilities to exercise scientifically. Thus, it highlights the characteristics of vocational P.E..

\section{Classify the Majors, Grasp the Characteristics and Physical Demand of Occupation}

Formerly, contents of P.E. curriculum in higher vocational colleges by using single science curriculum content of longitudinal arrangement, three-year university PE of each class consist of three semesters. First and second semester is common class, namely "sport and health I" and "sport and health II ", the main content is endurance running, hurdling, parallel bars, floor exercise, javelin, long jump, three grade five boxing, volleyball, basketball, calisthenics, etc. The third semester is special sports electives, including basketball, volleyball, table tennis, football, aerobic, yoga, etc. Throughout the course contents, almost with the students in the future occupation without direct contact, these, what echo "individualization of teaching content is deficient, it did not regard the development and needs of students as the starting point and destination of the course" ${ }^{\text {[2] }}$.

If we need to highlight the PE in vocational service for students' future work, in the first place, we should be accordance with “The People's Republic of China Occupation Classification” what organized by Ministry of Labor and Social Security, the State Bureau of Quality and Technical Supervision and the State Statistical Bureau, and then combined with the "Educational guidance directory of Professional Higher Vocational College(for Trail Implementation)"that implemented by the Ministry of Education in 2005.Last,the main body gesture to a position as the main line, from the 
point of view of occupation physical characteristics and make scientific classification of current vocational colleges' profession.

\begin{tabular}{|c|c|c|c|}
\hline \begin{tabular}{l}
\multicolumn{1}{c}{ Physical } \\
Character of \\
Occupation
\end{tabular} & $\begin{array}{l}\text { Occupation } \\
\text { Categories }\end{array}$ & Specific Post & $\begin{array}{l}\text { Character and } \\
\text { Physical Demand }\end{array}$ \\
\hline $\begin{array}{l}\text { Static } \\
\text { sitting } \\
\text { posture }\end{array}$ & $\begin{array}{l}\text { The first category: } \\
\text { the staff and } \\
\text { associated personnel }\end{array}$ & $\begin{array}{l}\text { Securities investment and } \\
\text { management, accounting, } \\
\text { secretarial, administrative } \\
\text { clerk, IT industry, electronic } \\
\text { commerce, library and archives } \\
\text { management etc. }\end{array}$ & $\begin{array}{l}\text { Mainly engaged in } \\
\text { mental work, the long } \\
\text { time work desk, gesture, } \\
\text { a smaller range of whole } \\
\text { body activity; head, } \\
\text { neck, shoulder, } \\
\text { requirements of upper } \\
\text { limb, finger, wrist } \\
\text { muscle endurance }\end{array}$ \\
\hline $\begin{array}{r}\text { Static } \\
\text { standing } \\
\text { posture }\end{array}$ & $\begin{array}{l}\text { The second } \\
\text { category: professional } \\
\text { and technical } \\
\text { personnel }\end{array}$ & $\begin{array}{l}\text { Drug management, medical } \\
\text { beauty technology, electronic } \\
\text { measurement technology and } \\
\text { instruments, sculpture art } \\
\text { design, sales, hotel reception } \\
\text { etc. }\end{array}$ & $\begin{array}{l}\text { Standing for long time, } \\
\text { working time to stand as } \\
\text { the main position; on } \\
\text { the waist and lower } \\
\text { extremity strength } \\
\text { requirements. }\end{array}$ \\
\hline $\begin{array}{l}\text { Flow } \\
\text { change } \\
\text { posture }\end{array}$ & $\begin{array}{l}\text { The fourth } \\
\text { category: commercial, } \\
\text { service industry } \\
\text { workers }\end{array}$ & $\begin{array}{l}\text { Railway attendants, indoor test } \\
\text { and control technology, } \\
\text { rehabilitation, nursing, } \\
\text { marketing (Sales), tour guide }\end{array}$ & $\begin{array}{c}\text { The body without a } \\
\text { fixed posture, sitting } \\
\text { posture, both standing; } \\
\text { on the whole body has } \\
\text { high quality } \\
\text { requirements }\end{array}$ \\
\hline $\begin{array}{l}\text { Factory } \\
\text { operating } \\
\text { posture }\end{array}$ & $\begin{array}{l}\text { The sixth category: } \\
\text { production, transport } \\
\text { equipment operators } \\
\text { and related workers }\end{array}$ & $\begin{array}{l}\text { Housing construction, road and } \\
\text { bridge engineering, mold } \\
\text { design and manufacturing, } \\
\text { vehicle inspection and repair }\end{array}$ & $\begin{array}{l}\text { The physical demands } \\
\text { of durable, high } \\
\text { sensitivity; need strong } \\
\text { upper extremity and } \\
\text { trunk muscle strength }\end{array}$ \\
\hline $\begin{array}{c}\text { Special } \\
\text { post posture }\end{array}$ & $\begin{array}{l}\text { The fifth category: } \\
\text { Agriculture, forestry, } \\
\text { animal husbandry, } \\
\text { fishery and water } \\
\text { conservancy industry } \\
\text { production personnel }\end{array}$ & $\begin{array}{c}\text { Tobacco cultivation, } \\
\text { engineering geological } \\
\text { exploration, irrigation and } \\
\text { drainage, rescue, police, public } \\
\text { security, civil aviation flight } \\
\text { attendant }\end{array}$ & $\begin{array}{l}\text { Relates to full body } \\
\text { posture; the physical } \\
\text { demands special, more } \\
\text { stringent requirements } \\
\text { on the physical }\end{array}$ \\
\hline
\end{tabular}

\section{Divide into Classes Based on Majors, Set Teaching Contents According to Physical Fitness}

Former higher vocational college P.E., whose main content to traditional sports as the core and purpose is to cultivating broad exercise skills, so as to improve the physical quality of the students, however," excellent occupation physical is security for students to cope with job , employments more need to adapt and to post occupation physical" ${ }^{\text {[3] }}$, so the sports teaching should after understanding the physical characteristics of occupation, break the traditional administrative class which according to the form of teaching subject, in accordance with the professional nature of Higher Vocational Colleges module to provide into three independent but complementary teaching contents, to protrude the new idea and core of health sports, lifelong sports. 
Occupation of Physical Course

\begin{tabular}{|c|c|c|}
\hline $\begin{array}{c}\text { Professional } \\
\text { Category }\end{array}$ & Course & Main Contents of Courses \\
\hline $\begin{array}{c}\text { Static sitting } \\
\text { posture }\end{array}$ & $\begin{array}{c}\text { Sitting } \\
\text { posture }\end{array}$ & $\begin{array}{c}\text { Strength training (neck, shoulder, back, waist, wrist muscle strength } \\
\text { and endurance) flexible training, (neck, shoulder, arm, wrist, chest, } \\
\text { back, waist and flexibility),relaxation training (relax muscles of } \\
\text { neck, shoulder muscles, lumbar muscle, back muscle), chair } \\
\text { exercises }\end{array}$ \\
\hline $\begin{array}{c}\text { Static } \\
\text { standing } \\
\text { posture }\end{array}$ & $\begin{array}{c}\text { Standing } \\
\text { posture }\end{array}$ & $\begin{array}{c}\text { Waist, abdomen muscle strength and endurance training, strength } \\
\text { and endurance training, physical training, etiquette training }\end{array}$ \\
$\begin{array}{c}\text { Flow change } \\
\text { posture }\end{array}$ & $\begin{array}{c}\text { Change } \\
\text { posture }\end{array}$ & $\begin{array}{c}\text { Endurance training (walking, dancing, jogging, rope skipping, } \\
\text { swimming, climbing stairs), sensitivity training(running, jumping } \\
\text { and other transmission speed game),psychological training (the } \\
\text { sports fitness, according to plan, vacation) }\end{array}$ \\
\hline $\begin{array}{c}\text { Factory } \\
\text { operating } \\
\text { posture }\end{array}$ & $\begin{array}{c}\text { Operating } \\
\text { posture }\end{array}$ & $\begin{array}{c}\text { The upper limb strength training, strength training } \\
\text { posture }\end{array}$ \\
\hline $\begin{array}{c}\text { Special post } \\
\text { posture }\end{array}$ & $\begin{array}{c}\text { Improve physical fitness, training (running, speed sensitive variable } \\
\text { jumping game) }\end{array}$ \\
\hline
\end{tabular}

\section{Occupational Disease Prevention Class}

"Occupation work process, itself...... It is conducive to the development of physical skills associated with occupation and occupational improvement. But occupational work itself is not the main means for development of occupation of physical fitness, this labor is according to the characteristics of different types of fixed in one position, action, get exercise is mainly that some organs forcibly, other organs are not effectively exercise, thus easy to cause the abnormal body shape." ${ }^{[4]}$ for example, standing type like lathe worker, planer, upper body leaning forward, chest, bow back for a long time on working, those postures especially easy to cause lumbar muscle strain, scoliosis nurse, barber, usher easily lead to varicose veins, backache, lumbar muscle strain and other common diseases. Sitting type secretarial, accounting, computer operators, a long time sitting in front of the computer, susceptible to cervical spine deformation, lumbar disc hernia ion, lumbar muscle strain. The tour guide, reporters posture changing class prone to systemic fatigue; the factory operation easy cause numbness in the upper limb, lower limb soreness in the buttocks.

Therefore, in the teaching of physical education in higher vocational colleges, in addition to offering occupation physical extracurricular, we should also consider how to the all-round develop the students' physical quality, enhance muscle strength, speed, endurance, flexibility, sensitivity. "According to the characteristics of different types of occupation skill, strengthen training associated with occupation, arrange some alternate and symmetrical action, make the comprehensive development of the body, taking corrective or preventive body malformation." [5]

\section{Healthy Lifestyle Class}

A healthy lifestyle is undoubtedly that a professional should have, it is self-evident that significance for work and life. The content of a healthy lifestyle is fairy simple, but to do is not easy, and very little higher vocational students can actually do it.

China is a big gold medal country in the Olympic Games , but "encountered embarrassment:80\% of the people don't exercise, patient increased 20\% in 15 years" [6] Ministry of education, the Sixth National Student Fitness and health survey result shows, "Chinese college students several health indicators showed a downward trend. The survey, with examining index of students' explosive force, flexibility, strength, endurance and physical quality by standing long jump, sitting and reaching, 
griping strength and running performance, found that students in addition to flexible quality index of 19 to 22 year old age group, the explosive force, strength, endurance levels decline further." ${ }^{\text {[7] }}$ Ministry of Education Sports Health and art education secretary Wang Dengfeng deeply worried, "if ordinary college students' physique did not significantly improve, human resource is impossible." ${ }^{[8]}$

\begin{tabular}{|c|c|c|}
\hline $\begin{array}{l}\text { Teaching } \\
\text { Content }\end{array}$ & Category & Specific Content and Function \\
\hline \multirow{3}{*}{$\begin{array}{l}\text { Apparatus } \\
\text { exercise }\end{array}$} & Exercise bike & Enhance the leg strength, improve the function of heart and lung \\
\hline & Treadmill & Enhance the body resistance, promoting blood circulation \\
\hline & Dumbbell & Improve the strength of shoulder, back, chest, waist \\
\hline \multirow{3}{*}{$\begin{array}{c}\text { Shape } \\
\text { exercise }\end{array}$} & Basic gait & $\begin{array}{l}\text { Soft step, rolling, toe step, step, step, transformation of Spring } \\
\text { Waltz }\end{array}$ \\
\hline & $\begin{array}{l}\text { Stance } \\
\text { training }\end{array}$ & Develop the habit of standing graceful, correct walking posture \\
\hline & $\begin{array}{l}\text { Walking } \\
\text { posture } \\
\text { training }\end{array}$ & To develop good walking posture, correct walking posture \\
\hline $\begin{array}{c}\text { Exercise } \\
\text { prescription }\end{array}$ & \multicolumn{2}{|c|}{$\begin{array}{l}\text { According to the individual circumstances of higher vocational students' tailored } \\
\text { exercises, amount of exercises, to guide the scientific fitness avoid occupation } \\
\text { disease }\end{array}$} \\
\hline
\end{tabular}

From the scholars' survey about the students' life way in Higher Vocational Colleges as well as the author of long-term to higher vocational students' understanding, it can be said, vocational college students, life way is worrying! Both male and female students, the morning of the first or second lesson do not to eat or not eat breakfast on time, besides, at lunch or dinner overeating is constant some thing, when there is no class or weekend ,sleep late be accustomed to, in order to play games, chat in QQ, read e-novels, watch movies...... Do not rest from 12pm to 5am is routing, in the whole day, most of students not only do not exercise , smoking, excessive drinking, blind to lose weight but also be not at all surprising. Data of "students' physical condition and lifestyle related research" of Jiangsu area 28 "occupation college ${ }^{[9]}$ shows that from the overall situation, life style of College Students' health accounted for only a few (about 1/4).

\begin{tabular}{|c|c|c|}
\hline Lifestyle Self-assessment Project & Male & Female \\
\hline Never Smoke & $62.7 \%$ & $94.32 \%$ \\
\hline Good Habit in Alcohol Medication & $9.87 \%$ & $10.56 \%$ \\
\hline Good Habit in Eating & $7.56 \%$ & $12.34 \%$ \\
\hline Good Habit in Exercise & $10.45 \%$ & $6.23 \%$ \\
\hline Stress Control in Good Condition & $16.12 \%$ & $20.56 \%$ \\
\hline
\end{tabular}

Compared to occupation physical education and occupation disease prevention education, healthy lifestyles lesson more highlight its importance and necessity, it is no exaggeration to say, a pressing matter of the moment is the physical education in Higher Vocational Colleges for all students, in accordance with the "national student physical health standard", physical testing, we should master the way of life and physical health condition of students, take intervention timely and effectively, adjustment measures, so that the college students gradually form a healthy lifestyle.

\begin{tabular}{|c|c|}
\hline Teaching Contents & Traditional Sports + Fun Sports Project \\
\hline Physical Fitness Test & $\begin{array}{c}\text { Height, weight, vital capacity, step test, 50 meters, 800 meters, } 1000 \\
\text { meters running, standing long jump, sit ups(female), grip }\end{array}$ \\
\hline $\begin{array}{c}\text { Develop a Healthy Way of } \\
\text { Life and Correcting the } \\
\text { Unhealthy Way of life }\end{array}$ & $\begin{array}{c}\text { No bad habits, no smoking, drinking (if have habits must be properly } \\
\text { control can not be developed to smoking, alcoholism), the law of life, } \\
\text { early to bed and early to rise, three meals a day to eat, adhere to } \\
\text { exercise every day(ball games, track and field); to correct bad habits }\end{array}$ \\
\hline
\end{tabular}

The teaching content of the above three module, can be assigned to :open healthy lifestyle classes in the first semester freshman year and open occupation physical class next semester, open 
occupation disease prevention in the two first semester. Indeed, the contents of sports teaching in higher vocational settings cannot be exhaustive, it also could not know without consulting an Oracle calculate the direction of the employment of students and the specific job, but even if the students can't get engaged in the work of professional counterparts, as long as the good life style, students can adapt to the new job as soon as possible, in the new position to explore culture methods physical occupation, do a job with skill and ease in occupation life.

In short, higher vocational colleges as the main position for social convey application skills of workers, it through the reform of teaching content, let the students during the school "to increase the cognition of future occupation, establish occupation sports consciousness, enhance students' occupation physical fitness, enhance physical theory level, learn to self training, self care for health and self treatment.".[10] only in this way, the students into the occupation career can be competent for work, and they will enjoy a happy life!

\section{References}

[1] Chen Jinxiong, Infiltrating of Occupation Training on SportsTteaching in Higher Vocational Colleges[J] Education and Occuoation, 2008, (36): 178

[2] Jiang Ruli, Guide University Physical Education with Scientific Outlook on Development [J] Education and Occupation,2010, (2): 187

[3] Yan Wen, Construction of Higher Vocational College Occupation Physical Teaching Model of $[\mathrm{J} / \mathrm{OL}]$.

Http://www.doc88.com/p-980478680439.html.2011-09

[4] [5] Zhou Yufeng, Journal of School Physical Education Curriculum in the Teaching, Occupation Physical Teaching Measures [J]. Jia Musi Institute of Education,2012, (07): 377

[6] [7] [8] Chinese Newsweek. Gold Country Suffered Embarrassment:80\% of the people don't exercise http://news.sina.com.cn/c/sd/2012-08-24/115125029596.shtml[J/OL],2012-08

[9] Peng Feng, Ni Shuangqin. Related Research and the Life Style of Students' Physique in Occupation Colleges, Sports Network http://www.chinatyxk.com/gb/tywk_v.asp?Bookid=644, 2012, (12)

[10] Zhang Qiang, Research on Physical Fitness Exercise Prescription Teaching Mode Based on Occupation [J] Everyone,2012, (10): 243-244 